\title{
TRANSMISI PENDIDIKAN KEAGAMAAN \\ TERHADAP KEBUDAYAAN MASYARAKAT DEMAK PERSPEKTIF ANTROPOLOGI
}

\author{
Thoifuri \\ STAIN Kudus, Jawa Tengah, Indonesia \\ toifuristain@gmail.com
}

\begin{abstract}
ABSTRAK
Penelitian ini memiliki tujuan untuk mengetahui proses transmisi pendidikan keagamaan dan kebudayaan dalam masyarakat Demak dalam konteks antropologis dengan jenis historisnaturalistik. Penelitian ini menggunakan metode kualitatif dengan metode induktif sebagai analisis data. Hasil dari penelitian ini berupa transmisi pendidikan keagamaan dan kebudayaan di masyarakat Demak dalam Pendidikan Keagamaan Pesantren. Dalam prosesnya menekankan belajar usia sekolah 7- 24 tahun, melengkapi sarana pendidikan dan memacu masyarakat dalam pendidikan non-formal (pesantren), memacu minat baca dan tulis masyarakat Demak yang dibungkus dengan semangat kehidupan religius, menerapkan sistem keyakinan, memelihara sistem ritus dan upacara, dst. Implikasinya terhadap kebudayaan masyarakat Demak berupa kualitas Sumber Daya Manusia, toleransi kehidupan beragama, tumbuh suburnya lembaga keagamaan sebagai agent of social change. Implikasi ini dengan menerapkan kurikulum yang bercorak Islami, ketaatan pada Allahs sesuai kebutuhan masyarakat, menghindari kontradiksi, memperhatikan perkembangan psikologis, dan penggunaan metode pembelajaran yang fleksibel.
\end{abstract}

Kata Kunci: Transmisi, Kebudayaan, Pendidikan, Agama. 


\begin{abstract}
The purpose of this study was to determine the transmission of religious education and culture in Demak society in the context of historical anthropological types-naturalistic. This study uses qualitative methods with inductive method for the data analysis. The results of this study in the form of religious education and cultural transmission in Demak society in Religious Education Pesantren. In the process emphasizes learning school aged 7- 24 years, completing facilities and spur public education in non-formal education (schools), stimulate interest in reading and writing Demak society wrapped in a spirit of religious life, implemented a system of beliefs, rites and ceremonies maintain systems, ff. Implications Demak cultural community in the form of quality of Human Resources, religious tolerance, the flourishing of religious institutions as an agent of social change. The implications of this by applying a patterned Islamic curriculum, obedience to God according to community needs, avoid contradictions, pay attention to psychological development, and the use of flexible learning methods.
\end{abstract}

Keywords: Transmission, Culture, Education, Religion

\title{
A. Pendahuluan
}

Setiap langkah manusia tidak lepas dari bingkai pendidikan, baik dalam wilayah hukum, politik, ekonomi, maupun sosial-budaya. Langkah tersebut didasari oleh kelebihan manusia berupa akal untuk menciptakan hal yang baru. Disinilah akal menjadi salah satu sumber kebenaran, disamping wahyu dan alam. Akal juga berperan untuk memperoleh, menggali dan memahami kebudayaan yang lebih baik. Hal ini tentunya didapat melalui aktivitas pendidikan, baik melalui jalur formal, informal, maupun non formal (pesantren).

Dalam UUSPN No. 20 Tahun 2003, Bab I, Pasal 1, ayat 1 merumuskan bahwa pendidikan adalah usaha sadar dan terencana untuk mewujudkan suasana belajar dan proses pembelajaran agar peserta didik secara aktif mengembangkan potensi dirinya untuk memiliki kekuatan spiritual keagamaan, pengendalian diri, kepribadian, kecerdasan, akhlak mulia, serta keterampilan yang diperlukan dirinya, masyarakat, bangsa dan negara. Khusus kaitannya dengan kekuatan spiritual keagamaan sebagaimana dalam UUSPN No. 20 Tahun 2003, Pasal 30, ayat 1, 2 dan 3 menyatakan pendidikan keagamaan diselenggarakan oleh Pemerintah dan/kelompok 
masyarakat dari pemeluk agama, sesuai dengan peraturan perundangundangan. Ayat ke 2 merumuskan bahwa pendidikan keagamaan berfungsi mempersiapkan peserta didik menjadi anggota masyarakat yang memahami dan mengamalkan nilai-nilai ajaran agamanya dan/ menjadi ahli ilmu agama. Dan ayat ke 3 bahwa pendidikan keagamaan dapat diselenggarakan pada jalur pendidikan formal, nonformal dan informal.

Kajian ini yang dimaksud adalah transmisi kebudayaan dalam jalur pendidikan non formal, yaitu pesantren. UUSPN No. 20 Tahun 2003, Pasal 55, ayat 1, Sebagai pendidikan keagamaan, pesantren (unit lembaga masyarakat) berhak menyelenggarakan pendidikan berbasis masyarakat pada pendidikan formal dan nonformal sesuai dengan kekhasan agama, lingkungan sosial, dan budaya untuk kepentingan masyarakat. Makna ini dapat memposisikan fungsi pendidikan sebagai pemelihara dan pentransmisi budaya, pentansformasi budaya, dan pengembang pribadi anak (Taba: 1962: 27).

Hidup dalam era global, dimana hubungan personal dan sosial sudah tidak bisa terbatasi waktu dan ruang yang disebabkan oleh pengaruh sistem ekonomi, pendidikan, dan organisasi sosial. Peleburan tersebut tercakup dalam konteks kebudayaan yang dimaknai sebagai keseluruhan pengetahuan, kepercayaan, seni, moral, hukum, adat, kemampuan dan kebiasaan yang didapatkan manusia dalam anggota masyarakat (Taylor, 1871: 21). Antropolog mendefinisikan kebudayaan adalah pengetahuan yang diperoleh manusia dan digunakan untuk menafsirkan pengalaman dan menimbulkan perilaku (Bagdan, 1982: 35).

Dengan demikian, antropologi mencoba tampil sebagai ilmu yang mempelajari manusia dengan harapan mempermudah pencapaian tujuan individu dan masyarakat dalam karakternya masing-masing. Dalam kata lain, antropologi melihat merubahan perilaku individu dan kolektif dari masa kemasa dengan disertai kelebihan dan kelemahannya. Disinilah antropologi pendidikan dapat diacu kembali dalam kajian mengenai masalah transmisi kebudayaan yang berarti penularan atau penyebaran kebudayaan.

Dalam hal ini M. Mead (1930 dan 1942) seorang antropolog yang sangat concern pada pendidikan mencoba mendiskripsikan 
penelitiannya tentang adat-istiadat pengasuhan anak serta masalah pertumbuhan remaja, bagaimana peran sekolah dalam transmisi dan perubahan kebudayaan dalam masyarakat yang berupa learning cultures (masyarakat belajar dengan cara tidak resmi sebagaimana kehidupan rutin sehari-hari) dan teaching cultures (masyarakat mendapat pelajaran secara resmi dari warga lain yang lebih tahu) (Koentjaraningrat, 1990: 228-230).

Masyarakat Demak dalam proses transmisi kebudayaan telah mengalami perubahan yang signifikan seiring dengan tuntutan global, baik perubahan pola pikir ekonomis, pendidikan, maupun perilaku yang agamis. Oleh karenanya, yang perlu mendapat perhatian adalah apakah kebudayaan yang awalnya terikat norma agama mampu mempengaruhi transmisi kebudayaan, atau sebaliknya, yaitu transmisi kebudayaan mempengaruhi kebudayaan religius.

Boleh dikata Demak merupakan masyarakat religius (mayoritas muslim), hal ini sesuai dengan data statistik Kabupaten Demak yang terdiri dari 14 Kecamatan, 241 Desa, dan 6 Kelurahan dengan jumlah penduduk sebanyak 1.036 .521 orang. Jumlah ini beragama Islam 99, $21 \%$, Kristen-Katholik 0,73 \% dan Hindu-Budha 0,06 \% (Demak Dalam Angka 2005). Data tersebut telah mengalami pergeseran nilai melalui transmisi dari trasendental ke modernitas atas implikasi masyarakat global. Dampak globalisasi akan menjadi ancaman negatif bagi masyarakat religius, terutama Demak, jika tidak memberdayakan potensi masyarakatnya melalui institusi pendidikan pesantren. Lembaga Keagamaan nonformal (pesantren) ini sebanyak 162 dengan jumlah santri 23.200 orang (12.349: putra dan 10.85: putri). Lembaga peribadatan (Masjid dan atau Mushalla) sebanyak 99,31 \%, Gereja Katholik dan Protestan sebanyak 0,69 \%). (Demak Dalam Angka 2005). Melihat potensi ini perlu adanya penerapan konsep "Teologi Transformatif” yakni bercorak mencetak akademisi yang mampu tampil dengan pendekatan rasionalisasi, mampu bersaing dengan kecenderungan barat yang hanya mengukur kebenaran secara rasional-empirik dengan bekal infrastuktur teknologi canggih (Abdurrahman, 1995: 107), yakni perilaku yang ingin melepaskan diri dari trasendensi. Modernitas ini sebagai produk gerakan renaisans yang telah ditegakkan atas sendi antroposentrik, rasionalisme (manusia menjadi ukuran segalanya) di barat abad XVI, 
kemudian berpuncak sekularisme, materialisme, dan ateisme abad XIX dan XX (Maarif, 1995: 94).

Terdapat momentum dalam masyarakat Demak yang telah mengalami transmisi kebudayaan, yaitu melalui "Grebeg Besar". Grebeg berarti digiring, dikumpulkan dan dikepung, dan Besar diambilkan dari bulan Dzul Hijjah. Pada bulan ini terjadi peristiwa besar bagi kaum muslimin yang berupa menunaikan ibadah haji dan melaksanakan korban. Dengan demikian, Grebeg Besar adalah suatu acara setahun sekali yang didatangi masyarakat muslim dari manapun mereka berasal di tempat khusus -sekitar Masjid Agung Demakdengan tujuan memperoleh siraman rohani yang berupa pengajian atau dakwah islamiyah sesuai dengan tujuan Walisongo. Akan tetapi, ironisnya sekarang justru momentum tersebut banyak disalahgunakan atau diselewengkan dari tujuan asalnya menjadi arena bisnis dan bernuansa tidak Islami.

Penyalahgunaan momentum tersebut dapat dilihat sebagai berikut: Pertama: banyaknya para pedagang yang berdatangan dengan model sewa tanah kaplingan jauh sebelum harinya Grebeg Besar tiba. Maksudnya mereka datang hanya berniat bisnis semata dengan tanpa memperhatikan aspek ritual (ibadah) islamiyah. Kedua; adanya bisnis adu untung dengan penyediaan hadiah yang melimpah. Ketiga; adanya tempat hiburan, seperti dangdut/orkes yang menampilkan penyanyi-penyanyi wanita berpakaian seronok, pornoaksi. Keempat; sebagai momentum melepas rindu (baca: pacaran muda-mudi) di berbagai tempat sekeliling arena Grebeg Besar.

Transmisi yang pada dasarnya merujuk pada perilaku masyarakat Demak menjadi beradab dan penyebaran norma agama sebagai bagian dari kehidupan hariannya justru menjadi suatu pertanyaan dengan melihat fenomena masyarakat yang semakin jauh dari peradaban islami dan penyebaran nilai agama yang tidak merata dari satu desa ke desa lain. Artinya, ada sebagian desa di wilayah Demak yang berpegang teguh pada nilai agama, sebaliknya, ada sebagian desa lain yang telah meninggalkan norma agama dalam perilakunya.

Dari latar belakang diatas penulis mencoba merumuskan menjadi beberapa pokok permasalahan diantaranya 1) Bagaimana 
transmisi pendidikan keagamaan dalam masyarakat Demak dalam konteks antropologis ?, 2) Bagaimana transmisi kebudayaan masyarakat Demak yang bersumber dari pendidikan Pesantren?, 3) Bagaimana implikasi transmisi pendidikan keagamaan terhadap kebudayaan masyarakat Demak perspektif antropologi?

Ruang lingkup penelitian ini adalah mempelajari tentang anthropos, yakni mengkaji masalah khusus perkembangan perilaku makhluk manusia hkususnya masyarakat Demak sejak transmisi kebudayaan abad kewalian, abad XV hingga sekarang. Dan banyak perubahan dengan adanya transmisi kebudayaan yang melalui pendidikan keagamaan pesantren.

Kajian ini mendasarkan pada pendekatan historis-naturalistik. Historis atau sejarah dalam arti penelitian yang kritis terhadap keadaan-keadaan, perkembangan, serta pengalaman di masa lampau dan menimbang secara cukup teliti tentang bukti validitas dari sumber sejarah serta interpretasi dari sumber-sumber keterangan tersebut (Nasir, 1999: 55).

Naturalistik dalam pengertian bahwa jenis ini lebih memilih metode kualitatif dari pada kuantitatif. Dan dimana menuntut agar diri sendiri atau manusia lain menjadi instrumen pengumpul data. Disamping itu analisis datanya menggunakan metode induktif, karena dengan cara tersebut konteksnya akan lebih mudah didiskripsikan (Muhadjir, 1998: 109). Oleh karenanya, pendekatan yang digunakan disamping fenomenologi, sejarah, juga pragmatisme meta-etis. Pendekatan fenomenologi ini mencoba menguraikan kebudayaan dan atau aspek-aspeknya yang dinamanakan etnografi, yaitu mempertimbangkan perilaku manusia secara baik sesuai dengan commen sense dalam masyarakatnya (Moleong, 1997: 13). Pendekatan sejarah yang dimaksud adalah menggunakan model singkronis, yaitu penulisan yang mengutamakan lukisan secara meluas dalam ruang, tanpa terlalu banyak memikirkan dimensi waktu, dan model diakronis, yakni penulisan yang lebih mengutamakan lukisan panjang berdimensi waktu, dengan hanya sedikit luasan ruangan (Kuntowijoyo, 1994: 36). Untuk pendekatan pragmatisme metaetis yang dimaksud adalah mencari makna etis dari suatu keputusan dalam bidang sosial yang beragam (Muhadjir, 1998: 109). 
Teknik yang ditempuh dalam penelitian ini adalah pengamatan dan wawancara. Pengamatan merupakan suatu cara untuk memperoleh gambaran mengenai pola budaya yang tidak diutarakan dengan kata-kata. Wawancara merupakan aktivitas untuk menggali keterangan mengenai cara berlaku yang telah menjadi kebiasaan, halhal yang telah dipercayai, dan nilai-nilai yang dianut (Ihromi, 1994: 51). Dalam hal ini tentunya tentang perubahan perilaku manusia dari satu masa ke masa berikutnya melalui pendidikan keagamaan pesantren pada masyarakat Demak.

\section{B. Pembahasan}

\section{Sekilas Sejarah Demak}

Kabupaten Demak secara geografis berada pada koordinat $110027^{\prime} 58$ " - $110048^{\prime} 47^{\prime \prime}$ bujur timur dan $6043^{\prime} 26$ " - 70 09'43" lintang selatan. Untuk lebih jelasnya, batas administrasi Kabupaten Demak sebelah utara (Kabupaten Jepara dan Laut Jawa), sebelah timur (Kabupaten Kudus dan Kabupaten Grobogan), sebelah selatan (Kabupaten Grobogan dan Kabupaten Semarang), sebelah barat (Kota Semarang). Dilihat dari ketinggian permukaan tanah dari permukaan laut (elevasi), wilayah Demak terletak mulai dari $0 \mathrm{~m}$ sampai dengan $100 \mathrm{~m}$ dari permukaan laut, yang dibatasi oleh tiga region, yaitu region A (Elevasi 0-3 m, meliputi sebagian besar Kecamatan Bonang, Demak, Karangtengah, Mijen Sayung dan Wedung. Region B (Elevasi 3-10 m, meliputi sebagian besar dari tiap kecamatan di Kabupaten Demak. Elevasi 10-25 m, meliputi sebagian Kecamatan Dempet, Karangawen dan Mranggen Elevasi 25-100 m, meliputi sebagian kecil dari Kecamatan Mranggen dan Kecamatan Karangawen. Region C (Elevasi dari 100 m, meliputi Kecamatan Karangawen dan Mranggen).

Adapun untuk jumlah penduduk Kabupaten Demak dalam angka 2005 didapatkan sebanyak 1,036,521 jiwa dengan prosentasi 49,42 \% jiwa penduduk laki-laki dan 50,58 \% jiwa penduduk perempuan.. Adapun sebaran penduduknya paling besar di Kecamatan Mranggen (127.131 jiwa), dan paling sedikit di Kecamatan Kebonagung (38.590 jiwa).

Dalam sejarah tercatat bahwa Kabupaten Demak merupakan 
kerajaan Islam pertama di pulau Jawa dengan nama Demak Bintoro dengan raja pertama, Raden Fatah, yang artinya pembuka (tanah). Menurut Babat Demak (Sejarah Perkembangan Islam di Jawa) Keraton Demak berdiri dengan tanda sengkalan "Geni Mati Siniraman Janmo" tahun 1403 Saka atau 1478 M. Namun ada yang mengacu pada condro sengkolo sirno ilang kertaning bhumi, tahun saka 1400 $($ sirna $=0$, ilang $=0$, kertaning $=4$, bumi $=1)$. Sedangkan menurut sejarawan berdirinya kota Demak sejak Raden Fatah dinobatkan sebagai Sultan Demak, 12 Robiul Awal tahun Saka 1425 (28 Maret 1503) sehingga setiap tanggal tersebut selalu diperingati sebagai hari jadi Kabupaten Demak.

Beliau putra Prabu Brawijaya kelima dengan istri Syarifah Champa binti Sayyid Zainul 'Alam al-Bulkiyah, Raja Kuntara Champa yang masuk Islam pada tahun 1300 saka/1378 M (Team Panitia Seabad Pon.Pes. Futuhiyyah Mranggen, 2001).

Dengan raja muslim, maka lembaga pendidikan yang dibangun adalah pesentren. "Pesantren" berasal dari kata "pe - santri - an”, dalam bahasa Sanskrit yang artinya masyarakat terpelajar, dan terbiasa dengan budaya baca-tulis. Budaya "baca" tersebut baik secara langsung (dalam buku teks) maupun tidak langsung yang berdasarkan pengalaman kesehariannya (alam atau lingkungan sekitarnya). Term "tulis" memberi makna bahwa santri dianjurkan untuk mencatat apa saja yang diberikan oleh kiai-nya agar materi kajiannya tidak lekas hilang dalam ingatan. Karena bagaimanapun ada suatu adigium bahwa sedikit tinta (suatu yang tercatat) itu lebih baik dari pada seribu ingatan (Bashori, 2003: xx).

Dalam dunia Pesantren yang berbasis doktrinitas Islam tentunya sudah berlangsung sejak kehidupan Rasulullah Saw. Hal ini terbukti adanya Darul Arqam di Makkah al-Mukarramah dan Pondok Suffah di Madinatul Munawwarah. Kemudian masuknya Islam di wilayah nusantara ini pada abad ke-7 di Samudra Pasai (Aceh). Bermula dari bentuk yang sederhana yakni rumah atau langgar, kemudian berkembang menjadi sebuah lembaga pendidikan yang sekarang dikenal dengan pesantren.

Khususnya di Jawa, pesantren bertambah subur atas dasar penerimaan dan masuknya Islam Ratu Shima Kalingga di Desa Keling 
Jepara, Jawa Tengah dengan bukti hukuman potong tangan bagi pencuri. Kemudian Syekh Rahmatullah (Makamnya di Garut) dalam dakwahnya selalu mendapat hambatan dari ayahnya sendiri yang menjadi Raja Pajajaran di Jawa Barat karena beda prinsip ideologi.

Generasi dakwah islamiyah terus berjalan hingga lahirnya Kerajaan Majapahit. Tampilnya Syekh Al-Jaly al-Khawaji al-Baghdadi al-Jawi yang dikenal dengan sebutan Ronggolawe dan sekaligus sebagai salah satu pendiri Majapahit dengan jabatan Adipati Tuban yang pertama. Adipati Tuban beserta keturunannya hingga Kanjeng Sunan Kalijaga Kadilangu telah banyak memuslimkan orang Jawa pada masa pemerintahan Majapahit sampai dengan munculnya Kerajaan/ Kasultanan Islam di Bintoro Demak.

Pesantren lahir di Demak karena komunitas muslim sangat membutuhkan adanya lembaga pendidikan keagamaan. Bermula dari bentuk yang sederhana yakni rumah atau langgar, kemudian berkembang menjadi sebuah lembaga pendidikan yang sekarang dikenal dengan pesantren. Komponen pesantren meliputi: Pesantren, lembaga pendidikan keagamaan (Islam) yang mempunyai ciri khas adanya kyai dan santri yang hidup dalam satu komplek (pondok). Kyai, pengasuh pondok pesantren dan menjadi sentral figur. Ustadz, guru senior yang membantu kyai dalam menyampaikan ilmu di pesantren. Santri, penuntut ilmu di pondok pesantren. Kitab Kuning, produk pemikiran para elit agamis (ulama) yang digali dari al-Qur'an dan al-Hadits yang merupakan referensi awal ajaran Islam. Haflah Akhirussanah, kegiatan ceremonial yang menunjukan berakhirnya tahun pelajaran. Fungsi Pesantren, sebagai lembaga pendidikan pengemban visi dan misi Islam, Sebagai lembaga pencetak generasi elit agamis, sebagai pelopor pembentukan akhlakul karimah. Sejarah tersebut menggambarkan bahwa Demak sangat kental dengan budaya religius, pendidikan nonformal keagamaan pesantren tumbuh subur seiring dengan trnsmisi kebudayaan masyarakat modern.

\section{Transmisi Pendidikan Keagamaan}

Bangsa Indonesia pasti menghendaki pendidikan yang berkualitas. Untuk mewujudkannya, masyarakat Demak hendaknya melakukan pelayanan pendidikan yang secara umum digambarkan sebagai berikut: 
Thoifuri

a) Setiap penduduk dapat mengenyam pendidikan keagamaan, khususnya usia sekolah (7-24 tahun), dengan tujuan dapat menekan angka buta huruf penduduk di Kabupaten Demak.

b) Meningkatnya sarana pendidikan serta memperluas partisipasi masyarakat dalam pendidikan luar sekolah dan pendidikan masyarakat (keagamaan).

c) Terwujudnya perkembangan minat baca dan tulis di sekolahsekolah, perpustakaan maupun di lingkungan masyarakat (Demak Dalam Angka 2005).

Untuk mewujudkan pelayanan tersebut perlu memposisikan komponen Pendidikan Keagamaan melalui institusi Pesantren atau Madrasah Diniyah secara proposional yang meliputi; tujuan, guru/kyai, anak didik/santri, metode, sarana-prasarana, lingkungan dan evaluasi/imtihan. Khusus posisi guru/kyai mempunyai peran dan tugas penting sebagai agent of social change, terutama proses pembelajaran untuk merubah perilaku murid-muridnya menjadi yang lebih baik.

Guru (kyai) adalah pendidik profesional dengan tugas utama mendidik, mengajar, membimbing, mengarahkan, melatih, dan mengevaluasi peserta didik pada jalur pendidikan formal dari tingkat sekolah dasar hingga menengah (UU RI No. 14 Tahun 2005 tentang Guru dan Dosen).

Karena perilaku seseorang (murid) selalu berubah sesuai dengan tingkat pertumbuhan fisik dan perkembangan psikis (pikirannya), disamping itu perubahan perilaku juga dapat dipengaruhi oleh kehidupan masyarakat global dengan seperangkat alat teknologi canggih. Maka untuk memahami kondisi seperti ini, peran Pendidikan Keagamaan Pesantren dalam masyarakat Demak tidak bisa lepas dari adanya transmisi pendidikan keagamaan dan kebudayaan.

Pendidikan keagamaan (pesantren) merupakan bagian dari pendidikan pada umumnya. Dalam konteks pendekatan etnografi di atas, pendidikan akan berhasil manakala dapat mendidik pembaca bagaimana sebaiknya berperilaku dalam suatu latar kebudayaan, apakah itu di antara keluarga-keluarga masyarakat hitam, di kantor kepala sekolah, atau di kelas taman kanak-kanak (Moleong, 1997: 13). 
Ini memberi maksud bahwa guru/kyai hendaknya mampu menjadikan anak didiknya (santri) peka terhadap transmisi kebudayaan dalam semua ruang dan waktu. Dengan demikian, anak didik/santri diberi kebebasan berbudaya dalam bingkai perilaku keagamaan melalui pendidikan yang lebih ideal.

Transmisi kebudayaan dalam Pendidikan Keagamaan Pesantren dapat berwujud komponen religi seperti: 1) Emosi keagamaan, yakni sesuatu yang menyebabkan manusia mempunyai sikap serba religi dalam bentuk getaran yang menggerakkan jiwa manusia. 2) Sistem keyakinan, yaitu berwujud pikiran dan gagasan manusia yang menyangkut keyakinan dan konsepsi manusia tentang sifat-sifat Tuhan, wujud alam ghaib, terjadinya alam dunia, zaman akhirat, roh nenek moyang, roh alam, dewa, roh jahat, hantu. 3) Sistem ritus dan upacara, yakni tindakan manusia dalam melaksanakan kebaktiannya terhadap Tuhan, dewa, roh nenek moyang, atau makhluk halus. 4) Peralatan ritus dan upacara, yaitu tempat/gedung pemujaan, masjid, langgar, gereja, pagoda, stupa, alat bunyi (orgel, genderang, bedug, gong, seruling, gamelan). 5) Umat agama, yakni berupa keluarga, kelompok kekerabatan, suku, marga, organisasi penyiar agama, organisasi gereja, partai politik agama (Koentjaraningrat, 1987: 80-82).

Dapatlah kita mengacau penelitian Fortes pada suku Tallensi di Taleland, Ghana Utara, tentang transmisi kebudayaan pendidikan pada umumnya, yaitu: Pertama: Unsur-unsur yang menyangkut proses fisiologi, refleks, gerak, reaksi, penyesuaian fisik yang diperlukan untuk dapat bertahan dalam masyarakat dan kebudayaan Tallensi. Kedua: Sikap psikologis serta berbagai perasaan yang perlu untuk maksud yang sama. Ketiga: Berbagai adat istiadat sosial, yang perlu untuk dapat berinteraksi dalam masyarakat Tallensi. Keempat: Berbagai konsep nilai budaya, adat istiadat, dan pandangan umum dalam kebudayaan Tallensi. Lebih lanjut, ia menegaskan bahwa proses transmisi kebudayaan masyarakat Tallensi adalah proses belajar dengan meniru orang yang lebih tua (Koentjaraningrat, 1990: 229).

Apabila ini diterapkan dalam tansmisi kebudayaan melalui Pendidikan Keagamaan Pesantren masyarakat Demak, maka ada persamaan dan perbedaan yang sangat signifikan. Persamaannya 
terdapat pada unsur pertama, karena refleks dan gerak sudah menjadi naluri kegiatan manusia dalam berbudaya yang menjadi akhlak mereka. Disamping itu, terdapat persamaan imitasi terhadap perilaku orang yang lebih tua. Adapun perbedaannya pada unsur kedua, ketiga dan keempat dengan argumentasi bahwa sikap psikologis, adatistiadat, nilai budaya pasti berbeda antar orang, suku dan bangsa dalam wilayah yang melatar belakanginya.

Adapun peran pendidikan keagamaan (pesantren) dalam transmisi kebudayaan masyarakat Demak dapat dilihat sebagai berikut:

a) Forum Silaturrahmi Kyai Demak, yang diantaranya kegiatannya adalah Bahtsul Masail, yaitu mengkaji peristiwa kekinian yang terkait pada problematika umat pada umumnya dan masyarakat Demak pada khususnya. Hasil dari kegiatan ini disampaikan kepada masyarakat Demak sebagai rujukan dalam kehidupan bermasyarakat.

b) Forum Silaturrahmi antar santri dalam bentuk kegiatan kompetisi baca kitab kuning dan kaligrafi Islam. Kegiatan ini bertujuan untuk memotivasi santri tekun belajar yang hasilnya untuk perubahan masyarakat secara agamis.

c) Adanya perpustakaan Masjid Agung Demak yang dipersiapkan untuk semua warga masyarakat Demak, kususnya para santri untuk rajin membaca ilmu dalam segala bidang sehingga memperluas wacana keilmuannya.

d) Menyiapkan sarana hiburan keagamaan secara bebas bagi siapa saja yang ingin tampil dengan disertai instrumen musik yang mendukungnya.

Peran Pendidikan Keagamaan Pesantren tersebut akan menjadi lebih maksimal dalam transmisi kebudayaan manakala dilakukan kerjasma antar berbagai pihak, pemerintah dan masyarakat, secara seimbang. Karena, dalam hal ini sesuai data yang penilati peroleh terutama para santri yang mau membaca ilmu-ilmu selain kitab kuning masih sedikit. Hal ini disebabkan oleh kurangnya buku bacaan umum di pesantren (sedikit yang mempunyai perpustakaan) dan yang lebih ironis lagi adalah ilmu selain kitab kuning masih dianggap kurang penting. 


\section{Transmisi Kebudayaan}

Mengacu pada makna kebudayaan di atas adalah keseluruhan pengetahuan, kepercayaan, seni, moral, hukum, adat, kemampuan dan kebiasaan yang didapatkan manusia dalam anggota masyarakat dan menimbulkan suatu perilaku, maka dapat dikatakan bahwa apapun aktivitas manusia berada dalam latar kebudayaan. Oleh karenanya, dalam transmisi kebudayaan tersebut perlu adanya aturan, norma dan nilai. Aturan dalam arti adanya seperangkat tata tertib dalam kehidupan masyarakat. Norma bermakna seperangkat hukum yang tidak mengikat adanya sanksi. Dan nilai adalah seperangkat hukum yang mengikat adanya sanksi.

Secara umum pembelajaran di pesantren untuk mentransmisi kebudayaan dapat dilihat dari: 1) Sistem pendidikan yang khusus (tradisional) untuk melatih santri memiliki kemampuan mandiri. 2) Heterogenitas umur santri dari usia 5 atau 10 hingga 25 tahun. 3) Waktu kajian materi sangat ketat dari pagi, siang, sore hingga malam. 4) Pakaiannya berciri khas sarung dan peci serta tempat duduknya adalah lantai. 5) Santri dewasa (senior) berperan mendidik yang lebih kecil. 7) Dan santri dewasa menekankan pembelajaran musyawarah atau diskusi (Horikoshi, 1987: 120-121).

Dalam hal ini apabila dikaitkan dengan transmisi kebudayaan masyarakat Demak melalui pendidikan keagamaan pesantren sebagai berikut:

\section{a. Pengetahuan}

Pendidikan di Pesantren mempunyai tradisi kuat dalam memelihara dan menghargai ilmu pengetahuan serta ilmuwannya (ulama/kyai). Ilmu dapat dijadikan media membuka tabir rahasia Tuhan melalui akal yang digunakan sebaik-baiknya. Dan ilmu pengetahuan yang dimiliki manusia akan menjadikan mereka alim, orang yang mengetahui dalam segala hal. Dengan demikian dapat dikata bahwa orang yang berilmu adalah mereka yang ada kaitannya dengan pengabdian pada Tuhan dalam konteks ajaran di pesantren.

Akan tetapi, dalam setting social kehidupan modern muncul berbagai tuntutan dalam mengkategorikan disiplin ilmu masingmasing yang mengarah pada kompetensi dan profesional seseorang. Tuntutan seperti ini, berimbas pada pemaknaan ulama yang semakin 
ambiguitas, ambivalen, mengambang. Maksudnya, ada statemen bahwa orang yang pandai dalam bidang ilmu tertentu, semisal: ahli nuklir, ahli perkapalan, ahli penerbangan, ahli pertanian, ahli kelautan, ahli perkonomian (ekonom), ahli politik (politisi), ahli hukum dan ahli-ahli lainnya menuntut pengakuan untuk mejadi ulama. Untuk itu yang menjadi pertanyaan adalah siapa sebenarnya ulama/kyai dalam pesantren?. Dalam perspektif doktrinitas agama Islam, orang dapat dikatakan ulama, apabila mempunyai beberapa persyaratan, yaitu: ketekunan beribadah kepada Tuhan, menguasai ilmu agama bersumber al-Quran dan al-Hadits, memahami hukum Islam yang bersumber dari kitab kuning, memahami bahasa Arab (ilmu alat: nahwu, sharaf, dll), mengamalkan ajaran Islam dengan baik dan benar, rajin mengamalkan ilmunya kepada siapa saja yang meminta, mempunyai karakter sabar, tawadlu, bersikap adil dan ikhlas.

Ilmu pengetahuan yang diajarkan dalam Pendidikan Keagamaan di pesantren pada umumnya dan Demak pada khususnya bersumber pada al-Quran dan al-Hadits, yang meliputi: akidah atau tauhid, fikih, dan akhlak atau tasawuf. Pengetahuan akidah/tauhid, mengajarkan tentang mengenal adanya Tuhan beserta sifat-sifatNya. Pengetahuan fikih mengenalkan tentang pemahaman aktivitas kehidupan manusia dalam interaksi sosialnya. Pengetahuan akhlak/ tasawuf, mengajarkan tentang kehidupan yang beretika.

Lembaga Pendidikan Keagamaan Pesantren di Demak mempunyai konstribusi cukup besar dalam mentranmisi kebudayaan masyarakat dalam berperilaku agamis yang dilandaskan pada pengetahuan yang diperoleh dari pesantren tersebut, sebagai contoh:

1) Pesantren Al-Amin di Kecamatan Mranggen, Kabupaten Demak. Pesantren ini dirintis oleh KH. M. Ridwan tahun 1987 dan sekarang teruskan oleh KH. Ma’sum dengan jumlah santri 162 (42 putra dan 122 putri). Program pendidikan yang disajikan meliputi: al-Qur'an dan Kitab Kuning. Dan pesantren ini memiliki sarana prasarana yang cukup memadai untuk menunjang aktivitas kegiatan santri, seperti; gedung pesantren, aula, masjid serta koperasi.

2) Dari hasil observasi, didapatkan bahwa Pesantren Attaslim yang didirikan oleh KH. Nurul Huda tahun 1989 ini beralamat 
di Jalan Kalijajar Kecamatan Demak Kota, Kabupaten Demak. Pesantren Attaslim memberi mata ajar al-Qur'an bin nadhor dan bil ghoib, serta kajian kitab kuning dengan jumlah santri 100 putra dan 105 putri. Sarana penunjang belajar santri diantaranya; kamar santri, gedung belajar, aula dan koperasi.

\section{b. Kepercayaan}

Sebagaimana data di atas bahwa Kabupaten Demak terdiri dari 14 Kecamatan, 241 Desa, dan 6 Kelurahan dengan jumlah penduduk sebanyak 1.036.521 orang. Jumlah ini beragama Islam 99, $21 \%$, Kristen-Katholik 0,73 \% dan Hindu-Budha 0,06 \%. Ini menunjukkan bahwa mayoritas penduduk Demak adalah berkeyakinan Islam.

Kepercayaan ini menumbuhkan motivasi dalam mendirikan lembaga-lembaga Islam (pesantren) untuk memperkuat kepercayaannya pada Tuhan dalam bentuk perilaku yang agamis. Islam (pesantren) memang mengajarkan suatu kepercayaan pada Tuhan yang bersifat ghaib. Disinilah perilaku kaum religius mempercayai bahwa manusia hendaknya meyakini bahwa alam ini didiami oleh makluk-makhluk halus yang lebih berkuasa daripadanya (Koentjaraningrat, 1987: 54). Terkait dengan transmisi kebudayaan melalui Pendidikan Keagamaan Pesantren di Demak, maka penduduk Demak telah menunjukkan perilaku yang didasarkan pada kepercayaan makhluk halus, seperti Tuhan dan Malaikat-Nya, sehingga perbuatannya akan terkontrol.

\section{c. Seni}

Untuk mentransmisi kebudayaan masyarakat Demak dapat dilakukan kegiatan sebagai berikut:

1) Memelihara budaya seni rabana sebagai wahana dakwah islamiyah. Seni ini sudah membumi dalam masyarakat Demak, baik di tingkat RW, RT, Desa, Kecamatan, hingga Kabupaten. Setiap tahunnya Remasade (Remaja Masjid Agung Demak) telah menyelenggarakan festival rabana yang diikuti oleh tiap kecamatan dari perwakilan desa masing-masing.

2) Adanya panggung hiburan anak-anak yang bertemakan "Aku Ingin Menjadi Anak Sholeh" dalam kemasan puisi atau tarian dari berbagai delegasi sekolah TK/RA di Kabupaten Demak, yang diselenggarakan tiap tahunnya. 
Thoifuri

\section{d. Moral}

Dalam Islam terdapat istilah akhlak yang diidentikkan dengan etika dan moral. Namun terdapat perbedaan dalam perspektif historis. Akhlak muncul dari bahasa Arab yang artinya penentuan batas aktivitas seseorang antara baik dan buruk, antara terpuji dan tercela tentang perkataan dan perbuatan manusia lahir dan batin berdasarkan ajaran Allah dan rasul-Nya.

Etika berasal dari bahasa Yunani "ethos" yang secara etimologis artinya adat kebiasaan. Sedangkan secara terminologis adalah aktiviatas yang dianggap baik dan buruk dengan memperhatikan amal perbuatan manusia sejauh yang dapat diketahui oleh akal pikiran. Moral berasal dari bahasa Latin "mores" adalah ide-ide yang umum diterima tentang tindakan manusia, mana yang baik dan wajar (Ya'qub, 1983: 14). Apabila Bandingkan dengan makna moral bagian dari norma: Disamping ada norma sopan santun dan hukum, juga ada norma moral. Norma sopan santun merupakan norma yang yang terkait dengan sikap lahiriah manusia. Norma hukum bermakna norma yang dituntut dengan tegas oleh masyarakat karena dianggap perlu demi keselamatan dan kesejahteraan umum. Dan norma moral adalah tolok ukur yang dipakai masyarakat untuk mengukur kebaikan seseorang (Suseno, 1987: 19).

Pemaknaan moral di atas jika dikaitkan dengan transmisi kebudayaan masyarakat Demak dapat dilihat dari kuantitas pemeluk Islamnya. Muslim di Demak tentunya memegang teguh pada moral yang dijarkan agama Islam, walaupun ada sebagian yang menyimpang darinya. Penyimpangan ini disebabkan oleh faktor internal dan eksternal. Faktor internal, karena adanya kurang kesadaran sebagaian tokoh agama (guru/kyai) itu sendiri yang sering mengganggap dirinya terbaik dan senang cari masa sebanyak-banyaknya sehingga mempengaruhi perilaku pengikutnya. Implikasinya adalah warga Demak terkotak-kotak karena fanatisme ajaran guru/kyai-nya. Sedangkan faktor eksternal adalah adanya pengaruh global yang menuntut perubahan ekonomi dengan kerja keras sehingga berimabas pada kehidupan individualis dan materialis. Ini semua sangat mempengaruhi transmisi kebudayaan pada masyarakat Demak untuk mengarah pada kesenjangan antara nilai-nilai agama dan dunia dengan tanpa memperhatikan nilai-nilai moralitasnya. 


\section{e. Hukum}

Sebagaimana lazimnya bahwa negara Indonesia adalah negara yang beragama, bukan agama yang bernegara. Karenanya, hukum yang diterapkan adalah hukum negara, walaupun hukum tersebut tidak keluar dari pondasi hukum agama. Terkait dengan hukum dalam transmisi kebudayaan masyarakat Demak, boleh dikata masyarakat Demak adalah taat hukum, baik produk pemerintah maupun hukum wahyu.

Melihat adanya ketaatan pada dua hukum tersebut, masyarakat Demak senantiasa berperilaku tidak jauh dari hukum tersebut. Hal ini dapat dibuktikan dengan maraknya menjalankan ajaran agama secara rutunitas dan acara-acara ritualitas dalam momentum tertentu. Dan ada sebagaian daerah kecil tertentu yang masih mengeliminir bahkan menganulir ajaran agama. Sebagai contoh, di kecamatan Wedung terdapat sekelompok masyarakat yang mengaku beragama Islam, namun shalatnya hanya tengah malam saja. Di kecamatan Bonang ada seorang tokok agama yang mereduksi ajaran agama, semisal shalat Jumatan tidak wajib bagi laki-laki.

Penyimpangan terhadap hukum dalam interaksi sosial ini sudah menjadi sunnatullah, yang disebabkan oleh kekurang pahaman mereka terhadap ajaran agama. Ini selaras dengan pernyataan Evans-Pritchard dalam bukunya Theories of Primitive Religion, yaitu mendikotomikan antara agama natural dan agama wahyu itu tidak benar dan menimbulkan kekaburan. Pernyataan ini, menjustifikasi bahwa masyarakat Demak dalam menjalankan hukum masih belum komprehensif, sehingga hukum hanya sebagai pengetahuan, belum menjadi suatu keyakinan.

Menurut Brian Morris, (terj) Imam Khoiri (2003: vii). Lebih lanjut dikatakan bahwa (hukum) dalam agama dilihat sebagai cara yang digunakan oleh kelas dominan untuk membuat bingung, dan mengontrol kaum petani dalam amsyarakat feudal, dan agama cenderung tidak melihat adanya institusi mediasi antara relasi produksi dan bentuk ideologi (Morris, 2003: 50).

\section{f. Tradisi}

Masyarakat Demak mempunyai tradisi tahunan yang dapat dijadikan transmisi kebudayaan agamis, yaitu Grebeg Besar yang acara 
Thoifuri

pokoknya:

a. Tanggal 7 Dzul Hijjah, grebeg dibuka resmi oleh Bupati Demak di depan/gapura Masjid Agung Demak.

b. Tanggal 8 - 9 Dzul Hijjah ceramah agama dan ziarah ke makam para pejuang Islam (dimulai dari Sultan Fattah).

c. Tanggal 10 Dzul Hijjah (malam Idul Adha) disamping acara takbiran diadakan juga upacara "Selamatan Tumpeng Sembilan” diarak dari Pendopo Kabupaten Demak yang dikawal oleh para prajurit Keraton dan pasukan terbang (rabana) menuju Masjid Agung Demak.

d. Tanggal 10 Dzul Hijjah pagi hari jam 06.30 diadakan shalat Idul Adha dilanjutkan dengan pemotongan hewan kurban.

e. Tanggal 10 Dzul Hijjah sekitar jam 08.00 upacara penjamasan pusaka Kanjeng Sunan Kalijaga yang berupa baju Ontokusumo dan dua keris (Kyai Crubuk dan Kyai Sirikan). Upacara ini dimulai dari Pendopo Kabupaten Demak yang dikawal para prajurit yang disebut Prajurit Patang Puluhan menuju ke lokasi makam Sunan Kalijaga di Kadilangu Demak (Syamlawi, 1985: 85).

\section{Implikasi Pendidikan Keagamaan Pada Kebudayaan}

Pesantren sebagai lembaga pendidikan yang bercorak agamis mempunyai konstribusi spektakuler dalam transmisi kebudayaan pada masyarakat Demak, yaitu membina kehidupan umat terutama dalam dimensi tauhid, ibadah, syariah maupun muamalah dan akhlaq/ tasawuf. Terwujudnya kehidupan sosial- budaya, kemasyarakatan yang agamis dan demokratis sebagaimana ini dipaparkan Demak adalah:

a. Terwujudnya kualitas Sumber Daya manusia yang makin meningkat. Peningkatan Sumber Daya Manusia dengan sendirinya harus meliputi kualitas matrial dan non material.

b. Terwujudnya toleransi kehidupan beragama dan nilai-nilai universal di Kabupaten Demak yang mayoritas penduduknya beragama Islam, maka titik berat pembangunan harus pada sektor pendidikan islami yang berwawasan kebangsaan.

c. Terwujudnya lembaga-lembaga keagamaan yang turut 
berperan sebagai agent of social change, dalam masyarakat dalam menopang terwujudnya masyarakat madani.

Implikasi pendidikan keagamaan pesantren di Demak ini mensyaratkan adanya pembenahan infrastruktur dan manajemen pesantren yang tidak hanya mempertahankan nilai-nilai konvensional, melainkan juga memacu diri pada perkembangan ilmu pengetahuan dan teknologi. Karena itu, secara umum pesantren sebagai lembaga pendidikan keagamaan yang bersumberkan al-Quran dan al-Hadits bervisi "Membentuk insan yang berwawasan dan berperilaku rahmatan lilalamin". Sedangkan misinya: membentuk santri yang beriman dan bertaqwa kuat pada Allah Swt. Menjadikan santri yang berakhlak mulia dan sebagai teladan. Mencetak santri yang cerdas, terampil, disiplin serta bertanggungjawab. Membentuk santri yang berkarakter mandiri. Membentuk santri yang peka terhadap fenomena sosial. Menjadikan santri yang berani berbuat amar ma'ruf dan nahi mungkar.

Implikasi transmisi kebudayaan ini tentu tidak lepas dari bentuk kurikulum yang diajarkan oleh pendidikan keagamaan pesantren berkarakter sebagai berikut: 1) Sesuai dengan fitrah manusia. 2) Memurnikan ketaatan pada Allah. 3) Sesuai dengan tujuan kebutuhan masyarakat. 4) Menghindari kontradiksi negatif. 5) Selaras dengan perkembangan psikologis. 6) Selaras dengan tujuan negara dan pemerintah daerah. 7) Penggunaan metode pembelajaran yang fleksibel. 8) Sesuai dengan aktivitas islami (jihad) yang proporsional.

Implikasi transmisi kebudayaan tersebut akan mudah diterima dan dilaksanakan masyarakat Demak, karena Pendidikan Keagamaan Pesantren di daerah ini mempunyai tipologi: Tauhid, mempertebal keimanan pada Allah SWT. Ibadah, implementasi ajaran agama seperti shalat, puasa, dan lain-lain yang disertai kualifikasi tertentu. Syariah, memberikan pemahaman tentang hukum Islam secara kaffah (menyeluruh) dengan berbagai konsekwensi bagi yang melaksanakan dan meninggalkan. Muamalah, meningkatkan interaksi sosial dalam bentuk peningkatan perekonomian-kesejahteraan, pendidikanpeningkatan kualitas Sumber Daya Manusia agar tidak gaptek (gagap teknologi).. Akhlak/tasawuf, pesantren membina moralitas yang disertai semangat spiritualisme dalam wadah thariqah. 
Thoifuri

\section{Simpulan}

Masyarakat Demak dalam proses transmisi kebudayaan telah mengalami perubahan yang cukup signifikan, baik perubahan pola pikir ekonomis, pendidikan, maupun perilaku yang religius. Artinya, norma agama mampu mempengaruhi transmisi kebudayaan pada masyarakat Demak, bukan kebudayaan mempengaruhi perilaku masyarakat Demak.

Norma agama yang mempengaruhi transmisi kebudayaan masyarakat Demak melalui Pendidikan Keagamaan Pesantren berwujud dalam semangat mencari ilmu pengetahuan, peningkatan kepercayaan/keimanan, meningkatnya budaya seni islami, peningkatan moralitas, sadar pada tertib hukum, melestarikan adat dan tradisi islami melalu grebeg besar.

Pendidikan keagamaan pesantren dalam transmisi kebudayaan dilakukan dengan langkah menekankan belajar usia sekolah 724 tahun (sarjana), melengkapi sarana pendidikan dan memacu masyarakat dalam pendidikan luar sekolah formal (pesantren), memacu minat baca dan tulis masyarakat Demak. Transmisi kebudayaan tersebut dipacu dengan semangat kehidupan religi, yakni: memacu emosi keagamaan, menerapkan sistem keyakinan, memelihara sistem ritus dan upacara, melengkapi peralatan ritus dan upacara, dan memberdayakan umat beragama.

Implikasi transmisi pendidikan terhadap kebudayaan masyarakat Demak berupa: kualitas Sumber Daya Manusia, munculnya toleransi kehidupan beragama, tumbuh suburnya lembaga keagamaan yang berperan sebagai agent of social change. Implikasi ini dengan menerapkan kurikulum yang bercorak Islami sesuai fitrah manusia, ketaatan pada Allah, Sesuai kebutuhan masyarakat, menghindari kontradiksi, memperhatikan perkembangan psikologis, dan penggunaan metode pembelajaran yang fleksibel. 


\section{DAFTAR PUSTAKA}

Abdurrahman, Moeslim. 1995. Islam Transformatif. Jakarta: Pustaka Firdaus.

Bagdan, Robert C dan Sari Knopp Biklen. 1982. Qualitative Research for Education: An Introduction to Theory and Methods. Boston: Allyn and Bacon, Inc.

Bashori, Khoiruddin. 2003. Problem Psikologis Kaum Santri. Yogyakarta: Forum Kajian Budaya dan Agama.

Horikoshi, Hiroko. 1987. A Traditional Leaders in a Time of Change: The Kijaji and Ulama in West Java. (terj) Umar Basalim dan Andi Muarly Sunrawa. Kyai dan Perubahan Sosial. Jakarta: P3M.

Ihromi, T.O., (ed). 1994. Pokok-Pokok Antropologi Budaya. Jakarta: PT. Gramedia.

Kuntjaraningrat. 1987. Sejarah Teori Antropologi I. Jakarta: UI-Press. Cet. II. 1990. Sejarah Teori Antropologi II. Jakarta: UI-Press. Cet. I.

Kuntowijoyo. 1994. Metodologi Sejarah. Yogyakarta: Tiara Wacana.

Maarif. Ahmad Syafii. 1995. Membumikan Islam. Yogyakarta: Pustaka Pelajar.

Moleong, Lexy J. 1997. Metodologi Penelitian Kualitatif. Bandung: PT. Remaja Rosdakarya.

Morris, Brian. (terj) Imam Khoiri. 2003. Antropologi Agama, Kritik Teori-Teori Agama Kontemporer. Yogyakarta: AK Group.

Muhadjir, Noeng. 1998. Metodologi Penelitian Kualitatif. Yogyakarta: Rake Sarasin.

Nasir, Moh. 1999. Metode Penelitian. Jakarta: Ghalia Indonesia. 
Thoifuri

Suseno, Franz Magni. 1987. Etika Dasar: Masalah- Maslah Pokok Filsafat Moral. Yogyakarta: Kanisius.

Syamlawi, Ichsan. 1985. Keistimewaan Masjid Agung Demak. Salatiga: CV. Saudara.

Taba, Hilda. 1962. Curriculum Development, Theori and Practice. New York: Harcourt, Brace \& World.

Taylor, E.B. 187. Primitive Culture. London: John Murray.

Team Panitia Seabad Pon.Pes. Futuhiyyah Mranggen. 2001. Sejarah Seabad Pondok Pesantren Futuhiyyah Mranggen Demak.

Thoifuri. 2007. Pesan-Pesan Pendidikan Profetik (Pedekatan Filosofis dan Fungsional). Kudus: Media Ilmu Press.

Undang-Undang Republik Indonesia. 2003. No 20 Tahun 2003 tentang Sistem Pendidikan Nasional, Semarang: Aneka Ilmu.

Undang-Undang Republik Indonesia. 2005. No 14 Tahun 2005 tentang Guru dan Dosen. Jakarta: Sinar Grafika.

Ya’qub, Hamzah. 1983. Etika Islam. Bandung: Diponegoro. 